\title{
IMPLEMENTASI TEKNIK BEHAVIOR CONTRACT UNTUK MEMOTIVASI SISWA DALAM PENYELESAIAN PEKERJAAN RUMAH (PR) DI MADRASAH TSANAWIYAH NEGERI (MTSN) PILANGKENCENG MADIUN
}

\author{
Muchammad Kahfi Chalimi \\ Program Pascasarjana Institute Agama Islam Tribakti Kediri
}

\begin{abstract}
Abstrak
Penggunaan metode pembelajaran yang tepat untuk meningkatkan mutu pembelajran harus terus ditingkatkan. Di samping itu pendampingan kepada siswa juga perlu dilakukan untuk mengarahkan siswa agartercapaitujuan belajarnya. Behavioral Contract(KontrakPerilaku) adalahsalah satuteknikpembelajaran pendekatan konseling terapi behavioral yang dapat digunakan untuk membantu menyelesaikan permasalahan perilaku maladaptif pada diri klien/konseli yang berkeinginan merubah perilaku tersebut menjadi lebih baik. Untuk mendalami teknik ini perlu diadakan penelitian.

Permasalahn yang diajukan dalam penelitianini meliputi :1) bagaimana implementasi teknik behavior contract untuk memotivasisiswa dalam penyelesai an PR. 2) bagaimana Hasil implementasi teknik behavior contract untuk memotivasi siswa dalam penyelesaian PR di MTsN Pilangkenceng Madiun .

Jenis penelitian yang dipilih adalah deskriptif kualitatif, adapun informan penelitiannya adalah kepala sekolah, guru bimbingan konseling, dan siswa. Dan tehnik pengumpulan data melalui observasi, wawancara dan dokumentasi.

Hasil penelitian menjelaskan, bahwa 1) implementasi teknis behavior contract ini ada beberapa tahap pelaksanaanya. Pertama konselor mengawali pertemuan dengan konseli untuk membentuk keakraban, dengan maksud agar tidak terjadi ketakutan atau kekakuan oleh konseli karena paradigma konseli setiap yang berhubungan dengan BK adalah menyeramkan. Keduda, menentukan data awal yakni tingkah laku dari konseli yang mana yang akan dirubah, dan dilanjut proses pembuatan kontrak antara konselor dengan konseli. Ketiga, konselor menetapkan jenis penguatan serta yang akan diterapkan setiap kali tingkah laku yang diinginkan ditampilkan oleh konseli, pemberian penguatan maupun reward kepada konseli diberikan sesering mungkin agar konseli semakin termotivasi. 2) Sementara hasil dari teknik behavior contract untuk memotivasi siswa dalam menyelesaikan PR siswa MTsN Pilangkenceng Madiun sudah cukup baik. Hasil dari proses konseling tersebut menyatakan bahwa kedua konseli itu menghasilkan berubahan perilaku yang cukup baik
\end{abstract}

Kata Kunci: Behavior Contract, Motivasi, Pekerjaan Rumah

\section{A. Konteks Penelitian}

Penggunaan metode pembelajaran yang tepat untuk meningkatkan mutu pembelajran harus terus ditingkatkan. Di samping itu pendampingan kepada siswa juga perlu dilakukan untuk mengarahkan siswa agar tercapai tujuan belajarnya. Behavioral Contract (Kontrak Perilaku) adalah salah satu teknik pembelajaran pendekatan konseling terapi behavioral yang dapat digunakan untuk membantu menyelesaikan permasalahan perilaku maladaptif pada diri klien/konseli yang berkeinginan merubah perilaku tersebut menjadi lebih baik. Untuk mendalami teknik ini perlu diadakan penelitian.

Pemberian tugas rumah adalah suatu metode yang digunakan dalam proses belajar mengajar dan mempunyai tujuan dan fungsi yang tersendiri. Dengan kegiatan melaksanakan tugas, siswa aktif belajar dan merasa terangsang untuk meningkatkan belajar yang lebih baik, 
serta memupuk inisiatif dan berani bertanggung jawab sendiri. Banyak tugas-tugas yang harus dikerjakan siswa. Hal itu diharapkan mampu menyadarkan siswa untuk selain memanfaatkan waktu sengganggnya untukhal-hal yang menunjang belajarnyadenganmengisikegiatan-kegiatan yang berguna dan konstruktif pemberian tugas rumah. Pemberian tugas pada akhir pengajaran adalah untuk lebih memahami materi yang diajarkan di dalam mencapai hasil yang diharapkan. ${ }^{1}$

Bagi orang tua, PR merupakan suatu "alat bantu" yang sangat penting bagi kegiatan belajaanak dirumah. Dikatakan sangat penting karena bagi sebagian besar orang tua, PR merupakan suatu "paksaan" bagi anak-anaknya supaya tetap belajar di rumah, supaya waktu tidak melulu diisi dengan bermain game di depan Playstation atau menonton film. Sebagian besar orang tua mengakui bahwa mereka tidak sanggup menyuruh anaknya belajar jika dari sekolah anaknya tidak dibebani dengan setumpuk PR.Menurut pengakuan mereka, tanpa PRanakanak menjadi malas belajar bahkan sama sekali tidak mau membuka bukupelajaran. Meskipun tidak jarang para orang tua sendiri menjadi "bulan-bulanan" PR anak-anaknya karena harus membantu proses penyelesaiannya.

Pada akhirnya, kita akan melihat siswa yang sungguh-sungguh mengerjakan PR adalah yang benar-benar ingin meningkatkan wawasan kemampuannya. Bukan sematademi meraih nilai atau menghindari hukuman gurunya. Kita jugaakan melihat orang tua yang sungguh mendorong anaknya untuk mengerjakanPR, memaksimalkan potensi yang ada pada diri anak sendiri tanpa terlibat secara langsung di dalam proses penyelesaiannya. ${ }^{2}$

\section{B. Fokus Penelitian}

Focus penelitian in di rinci menjadi dua hal yakni: 1) Bagaimana teknik behavior dengan prosedur contract dapat memotivasi siswa dalam menyelesaikan tugas pekerjaan rumah (PR) pada siswa Madrasah Tsanawaiyah

1 http://andasabar.blogspot.com/2012/06/pengaruhpemberian-tugas-rumah-terhadap.html

2 http://bambangpurnama.blogspot.com/2008/02/esensipemberian-pekerjaan-rumah-pr.html
Negeri (MTsN) Pilangkenceng Madiun. 2) Bagaimana hasil teknik behavior dengan prosedur contract dalam memotivasi siswa dalam menyelesaikan tugas pekerjaan rumah (PR) pada siswa Madrasah Tsanawaiyah Negeri (MTsN) Pilangkenceng Madiun.

\section{Tinjauan Tentang Teknik Kontrak Perilaku (Behavior Contract)}

Kontrak perilaku (behavior contract) yaitu mengatur kondisi konseli menampilkan tingkah laku yang diinginkan berdasarkan kontrak antara konseli dan konselor. ${ }^{3}$

Menurut Latipun kontrak perilaku (behavior contract) adalah persetujuan antara dua orang atau lebih (konselor dan konseli) untuk mengubah perilaku tertentu pada konseli. Konselor dapat memilih perilaku yang realistik dan dapat diterima oleh kedua belah pihak. Setelah perilaku dimunculkan sesuai dengan kesepakatan, ganjaran dapat diberikan kepada konseli. Dalam terapi ini ganjaran positif terhadap perilaku yang dibentuk lebih dipentingkan dari pada pemberian hukuman jika kontrak perilaku tidak berhasil. ${ }^{4}$

\section{Syarat-syarat Dalam Memantapkan Kontrak Perilaku}

Syarat-syarat dalam memantapkan kontrak perilaku adalah:

a) Adanya batasan cermat mengenai masalah konseli, situasi masalah itu muncul, danKesediaan konseli untuk mencoba suatu prosedur. b) Selain itu tugas mereka perlu dirinci, dan criteria sukses disebutkan serta reinforcement-nya ditentukan. Kalau semua itu ada, kontrak akan dapat dimantapkan melalui reinforcement yang cukup dekat dengan tugas dan kriterium yang diharapkan.

\section{Prinsip Dasar Kontrak}

Menurut Gantina, prinsip dasar kontrak perilaku adalah sebagai berikut: a) Kontrak disertai dengan penguatan, b) Reinforcement

3 Komalasari, Teori dan Teknik Konseling, 2011, hal. 172

4 Latipun, Psikologi Konseling, 2008, hal. 120 
diberikan dengan segera, c) Kontrak harus dinegosiasikan secara terbuka dan bebas serta disepakati antara konseli dan konselor, d) Kontrak harus fair jelas dan terbuka, e) Kontrak harus jelas (target tingkah laku, frekuensi, lamanya kontrak), f) Kontrak dilaksanakan secara teritegrasi dengan program sekolah. ${ }^{5}$

\section{Tujuan Kontrak Perilaku}

Menurut Lutfi Fauzan tujuan kontrak perilaku adalah sebagai berikut: a) Menciptakan kondisi baru bagi belajar (memperoleh tingkah laku baru), b) penghapusan tingkah laku maladaptif, c) memperkuat \& mempertahankan tingkah laku yang diinginkan, d) tujuan utama yaitu meningkatkan pilihan pribadi dan untuk menciptakan kondisi - kondisi baru dalam belajar. $^{6}$

\section{B. Tinjauan Tentang Motivasi}

Motivasi (motivation) adalah kekuatan yang menggerakkan seseorang untuk berperilaku, berpikir dan merasa seperti yang mereka lakukan. Perilaku yang termotivasi diberi kekuatan, diarahkan, dan dipertahankan. Para psikolog telah mengajukan serangkaian teori mengenai mengapa organisme termotivasi

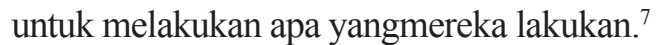

Motivasi adalah proses yang menjelaskan intensitas, arah, dan ketekunan seorang individu untuk mencapai tujuannya. ${ }^{8}$

Menurut kamus, motivasi berasal dari kata motif yang berarti "dorongan" atau rangsangan atau "daya penggerak" yang ada dalam diri seseorang. Menurut Weiner yang dikutip Elliot et al. motivasi didefenisikan sebagai kondisi internal yang membangkitkan kita untuk bertindak, mendorong kita mencapai tujuan tertentu, dan membuat kita tetap tertarik dalam

5 Komalasari, Teori dan teknik konseling. 2011, hal. 173

6 Fauzan,lutfi. 2009.KontrakPerilaku.Dalam http:lutfifauzan.wordpress.com/2009/kontrak-perilaku

7 Laura A. King, Psikologi Umum Sebuah Pandangan Apresiatif, (Jakarta: Salemba Humanika, 2007), hal. 64

8 Mitchell, T. R. penelitian dalam organisasi behavior (Greenwich, CT: JAI Press, 1997), hal. 60-62 kegiatan tertentu. Menurut Uno, motivasi dapat diartikan sebagai dorongan internal dan eksternal dalam diri seseorang yang diindikasikan dengan adanya; hasrat dan minat; dorongan dan kebutuhan; harapan dan citacita; penghargaan dan penghormatan. Motivasi adalah sesuatu apa yang membuat seseorang bertindak, Sargent menyatakan bahwa motivasi merupakan dampak dari interaksi seseorang dengan situasi yang dihadapinya. ${ }^{9}$

\section{Teori-teori Motivasi}

\section{a. Teori hierarki kebutuhan}

Teori motivasi yang paling terkenal adalah hierarki teori kebutuhan milik Abraham Maslow. ${ }^{10}$ Ia membuat hipotesis bahwa dalam setiap diri manusia terdapat hierarki dari lima kebutuhan, yaitu fisiologis (rasa lapar, haus, seksual, dan kebutuhan fisik lainnya), rasa aman (rasa ingin dilindungi dari bahaya fisik dan emosional), sosial (rasa kasih sayang, kepemilikan, penerimaan, dan persahabatan), penghargaan (faktor penghargaan internal dan eksternal), dan aktualisasi diri (partumbuhan, pencapaian potensi seseorang, dan pemenuhan diri sendiri).

Maslow memisahkan lima kebutuhan ke dalam urutan - urutan. Kebutu han fisiologis dan rasa aman dideskripsikan sebagai kebutuhan tingkat bawah sedangkan kebutuhan sosial, penghargaan, dan aktualisasi diri sebagai kebutuhan tingkat atas. Perbedaan antara kedua tingkat tersebut ada- lah dasar pemikiran bahwa kebutuhan tingkat atas dipenuhi secara internal dan kebutuhan tingkat rendah secara dominan dipenuhi secara eksternal.

\section{b) Teori $\mathrm{X}$ dan teori $\mathrm{Y}$}

Douglas McGregor menemukan teori $\mathrm{X}$ dan teori Y setelah mengkaji cara para manajer berhubungan dengan para karyawan. ${ }^{11}$

9 http://www.pengertianahli.com/2013/09/pengertian-motivasi-menurut-para-ahli.html

10 Abraham Harold Maslow,Motivasi dan Kepribadian, ( New York: Harper \& Row, 1954), hal. 57-67

11 A. Judge, Perilaku Organisasi, (Jakarta: Salemba Empat),hal. 222-232 
Kesimpulan yang didapat adalah pandangan manajer mengenai sifat manusia didasarkan atas beberapa kelompok asumsi tertentu dan mereka cenderung membentuk perilaku mereka terhadap karyawan berdasarkan asumsi-asumsi tersebut.

\section{c) Teori motivasi kontemporer}

Teori motivasi kontemporer bukan teori yang dikembangkan baru-baru ini, melainkan teori yang menggambarkan kondisi pemikiran saat ini dalam menjelaskan motivasi karyawan. ${ }^{12}$

\section{Area Motivasi Manusia}

Empat area utama motivasi manusia adalah makanan, cinta, seks, dan pencapaian..$^{13}$ Tujuantujuan yang mendasari motivasi ditentukan sendiri oleh individu yang melakukannya, individu dianggap tergerak untuk mencapai tujuan karena motivasi intrinsik (keinginan beraktivitas atau meraih pencapaian tertentu semata-mata demi kesenangan atau kepuasan dari melakukan aktivitas tersebut), atau karena motivasi ekstrinsik, yakni keinginan untuk mengejar suatu tujuan yang diakibatkan oleh imbalanimbalan eksternal. disamping itu terdapat pula fsktor yang lain yang mendukung diantaranya ialah faktor internal yang datang dari dalam diri orang itu sendiri.

\section{Pekerjaan Rumah}

Pengertian Pekerjaan Rumah/Resitasi Menurut Oemar Hamalik ialah sebagai berikut: "Pekerjaan rumah ialah suatu tugas yang diberikan oleh guru kepada murid-murid, tugas mana dikerjakan dan diselesaikan serta dipecahkan di rumah, dalam hubungannya dengan suatu mata pelajaran atau beberapa mata pelajaran. Pekerjaan rumah memberikan kesempatan belajar di rumah dan kegiatankegiatan ini merupakan pelengkap bukan sebagai duplikat dari kegiatan belajar di sekolah. Pekerjaan rumah mengandung 3 (tiga) unsur

12 Ibid, hal. 229-239

13 Carol, Wade, Carol, Tavris, Psikologi: Jilid 2,( Jakarta: Erlangga, 2007), hal. 142-152 yakni: (a) unsur tugas, (b) unsur belajar (home study), (c) unsur penilaian."

Sementara itu, Nana Sudjana mengemukakan bahwa "tugas dan resitasi tidak sama dengan pekerjaan rumah, tetapi jauh lebih luas dari itu. Tugas bisa dilaksanakan di rumah, di sekolah, dan perpustakaan, dan di tempat lainnnya." Oleh sebab itu, adanya perbedaan dari pendapat tersebut, bahwa pada dasarnya pengertian metode resitasi maupun pekerjaan rumah harus dapat merangsang para siswa untuk aktif belajar baik secara individual maupun secara kelompok. Dalam pelaksanaan metode ini siswa dapat mengerjakan tugasnya tidak hanya di rumah, mungkin di perpustakaan, di laboratorium, di kebun percobaan dan sebagainya untuk dipertanggung jawabkan kepada guru.

Dengan demikian, dari uraian tersebut dapat diambil suatu kesimpulan bahwa pekerjaan rumah maupun resitasi yaitu untuk memberikan selingan variasi teknik penyajian ataupun dapat berupa pekerjaan rumah. Tugas semacam itu dapat dikerjakan di luar jam pelajaran, di rumah maupun sebelum pula, sehingga dapat dikerjakan bersama temannya.

\section{Tujuan Pekerjaan Rumah}

Teknik pemberian tugas (pekerjaan rumah) biasanya digunakan dengan tujuan. Agar hasil belajar siswa memuaskan, guru perlu merumuskan tujuan yang jelas hendak dicapai oleh para siswa. Hal ini dikemukakan oleh Imam Sutari Bernadib merumuskan ialah sebagai berikut:

a. Merangsang agar siswa berusaha lebih baik, memupuk inisiatif, bertanggung jawab dan berdiri sendiri.

b. Membawa kegiatan sekolah yang berharga kepada minat siswa yang masih terluang. Waktu terluang dari murid agar dipergunakan secara konstruktif.

c. Memperkuat hasil belajar sekolah dengan menyelenggarakan latihanlatihan yang perlu di rumah. 


\section{Metode Penelitian}

Penelitian yang dilakukan oleh peneliti merupakan penelitian berjenis kualitatif tentang Implementasi Teknik Behavior Contract Untuk Memotivasi siswa dalam menyelesaikan Tugas Pekerjaan Rumah (PR) Di Madrasah Tsanawiyah Negeri (MTsN) Pilangkenceng Madiun, sedangkan pendekatan penelitian ini menggunakan pendekatan deskriptif kualitatifdengan melakukan analisa yang bersifat kualitatif. Dalam penelitian kualitatif data yang dikumpulkan bukan angka-angka, akan tetapi berupa kata-kata atau gambaran. Data yang dimaksud berasal dari wawancara, catatan lapangan, foto, dokumen pribadi dan lainnya. ${ }^{14}$ Karena dalam penelitian ini berbentuk deskriptif kualitatif, maka untuk menganalisa data (baik dari literatur maupun hasil penelitian) akan dianalisa dengan menggunakan teknik analisa, deskriptif kualitatif adalah suatu analisa yang menggambarkan obyek penelitian dengan didukung data yang bersifat kualitatif atau uraian kata-kata atau kalimat.

Penelitian ini berkenaan dengan kondisi atau hubungan yang ada: praktek-praktek yang sedang berlaku, keyakinan, sudut pandang atau sikapyang dimiliki, proses-proses yang berlangsung, pengaruh-pengaruhyang sedangdirasakan, atau kecenderungankecenderungan yangsedang berkembang. ${ }^{15}$

\section{B. Lokasi Penelitian}

Adapun lokasi penelitian ini berada di kota Madiun Propinsi Jawa Timur, tepatnya di Madrasah Tsanawiyah NegeriPilangkenceng, yang terletak di Jl.Raya Pilangkenceng, kecamatan PilangkencengMadiun.

Dalam penelitian kualitatif, kehadiran peneliti bertindak sebagai instrumen sekaligus pengumpul data. Kehadiran peneliti mutlak diperlukan, karena disamping itu kehadiran peneliti juga sebagai pengumpul data. Sebagaimana salah satu ciri penelitian kualitatif dalam pengumpulan data dilakukan sendiri oleh peneliti. Sedangkan kehadiran

14 Lexy J. Moleong, Metodologi Penelitian Kualitatif, (Bandung: PT. Remaja Rosda karya,1996), hal. 11

15 Ibid., hal. 50 peneliti dalam penelitian ini sebagai pengamat partisipan/berperan serta, artinya dalam proses pengumpulan data peneliti mengadakan pengamatan dan mendengarkan secermat mungkin sampai pada yang sekecil-kecilnya sekalipun.

\section{Analisis Data}

Analisis merupakan langkah terakhir dalam penelitian ini, yang mana peneliti akan menganalisa data-data yang diperoleh dari hasil wawancara dan observasi yang mendukung terselesainya penelitian ini. Data-data yang akan dianalisa ini merupakan data yang berhubungan dengan kasus yang telah diteliti tentang "Implementasi Teknik Behavior Contract Untuk Memotivasi siswa dalam menyelesaikan Tugas (PR) Di MTSNPilangkencengMadiun" Dengan demikian peneliti mencoba menganalisa data sesuai dengan temuan-temuan dilapangan yang berhubungan dengan teori yang ada dari penelitian yang peneliti lakukan di MTsN Pilangkenceng Madiun.

Dalam proses pelaksanaan teknik kontrak perilaku untuk memotivasi siswa dalam menyelesaikan PR ini, peneliti mengamati pelaksanaan konseling yang sedang berlangsung antara konselor dengan konseli $\mathrm{X}$ dan Y dalam beberapa waktu. Dalam proses konseling yang dilakukan oleh konselor dan dua konseli, peneliti melihat dan mendapat beberapa fenomena yang terjadi.

Dalam pelaksanaan proses konseling ini peneliti mengamati setiap jalannya proses konseling, mulai dari saat pertemuan awal konselor dengan konseli, yang mana konselor mulai mencoba membuat hubungan yang akrab dengan konseli agar konseli merasa nyaman saat proses konseling. Dan peneliti juga mengikuti proses saat konselor dan konseli membuat kontrak secara bersama dengan tujuan merubah perilaku konseli yang kurang baik menjadi lebih baik lagi. Dalam kontrak itu antara konselor maupun konseli harus samasama setuju tanpa adanya busaan.

Seperti halnya disebutkan oleh Gantina dalam bukunya "teori dan teknik konseling", 
terdapat tahap dalam melaksanakan kontrak perilaku, diantaranya: a) Memilih tingkah laku yang akan diubah dengan melakukan analisisABC, b) Menentukan data awal (tingkah laku yang akan diubah), c) Menentukan jenis penguatan yang akan diterapkan, d) Memberikan reinforcement setiap kali tingkah laku yang di inginkanditampilkan sesuai jadwal kontrak, e) Memberikan penguatan setiap saat tingkah laku yang ditampilkanmenetap. ${ }^{16}$

Konselor MTsN Pilangkenceng dalam menerapkan teknik kontrak perilaku pada siswa juga tidak jauh berbeda dengan teori yang ada. Dibuktikan dengan hasil wawancara dan observasi peneliti saat proses konseling dengan konselor, yakni pada awal pertemuan yang dilakukan antara konselor dengan konseli adalah membentuk keakraban, maksudnya antara konselor dengan konseli harus memiliki keakraban agar tidak terjadi ketakutan atau kekakuan yang dimiliki konseli karena paradigma konseli setiap yang berhubungan dengan BK adalah menyeramkan setelah itu konselor mencoba menganalisis permasalahan yang terjadi dengan melihat penyebab dari terbentuknya perilaku konseli serta dambu yang muncul akibat perilaku tersebut. Pada tahap kedua adalah menentukan data awal yakni tingkah laku dari konseli yang mana yang akan dirubah, setelah mendapat data tentang tingkah laku manayang akan diubah selanjutnya adalah proses pembuatan kontrak antara konselor dengan konseli, tahap selanjutnya konselor menetapkan jenis penguatan serta yang diterapkan setiap kali tingkah laku yang diinginkan ditampilkan oleh konseli, pemberian penguatan reward kepada konseli diberiakn sesering mungkin agar konseli semakin termotivasi untuk melaksanakan isi dari kontrak yang sudah dibuat, penguatan juga harus diberikan setiap kali tingkah laku yang diinginkan ditampilkan sesuai jadwal kontrak dan dilakukan secara menetap oleh konseli.

Dalam proses konseling ini, peneliti diberi kesempatan oleh konselor untuk mengamati jalannya proses konseling dengan teknik behavior contract, yang menjadi masalah inti yang harus diubah oleh konselor serta konseli

16 Komalasari, Teori dan tekhnik Konseling. 2011, hal 175
$\mathrm{X}$ dan $\mathrm{Y}$ adalah rendahnya motivasi kedua konseli tersebut dalam mengerjakan PR

\section{Hasil Teknik Behavior Contract Dalam} Memotivasi Siswa untukmenyelesaikan Tugas Pekerjaan Rumah di MTsN Pilangkenceng Madiun.

Setelah peneliti mengikuti dan mengamati proses konseling yang dilakukan pada intensitas waktu yang sama oleh konselor, peneliti dapat menyimpulkan hasilnya yakni antara konseli X dan Y setelah dilakukannya proses konseling memiliki perbedaan sikap. Jadi sudah jelas bahwa tujuan dari teknik behavior contract yang mengubah perilaku maladaptif menjadi adaptif kini terlihat. Namun hasil antara konseli $\mathrm{X}$ dan $\mathrm{Y}$ berbeda, konseli $\mathrm{Y}$ lebih menambukan dan mengasilkan perilaku baru yang sesuai dibanding konseli $\mathrm{X}$.

Seperti yang diungkapkan oleh Lutfi Fauzan bahwa tujuan dari kontrak perilaku (behavior contract) adalah penghapusan tingkah laku maladaptif, dan menciptakan kondisi-kondisi baru (memperoleh perilaku baru), dalam hal ini adalah kondisi memiliki motivasi untuk selalu mengerjakan PR.

Jadi, antara konselor dengan konseli Y telah berhasil dalam proses konseling dengan teknik behavior contract, sedangkan antara konselor dengan konseli $\mathrm{X}$ bukan berarti proses konseling mereka gagal, akan tetapi konseli X harus lebih mendapat konseling secara intensif.

Untuk konseli yang masih belum mendapat hasil yang baik dalam pelaksanaanteknik behavior contract, teknik tersebut tidak hanya dapat diterapkan antara konselor dengan konseli saja melainkan teknik tersebut dapat dilakukan oleh diri sendiri, yang dalam teorinya disebut " Self Contract" . dan jika hal itu dirasa kurang efisien pelaksanaannya, maka dapat meminta bantuan teman atau keluarga atau siapapun yang dianggap dapat membantunya dalam proses kontrak tersebut.

\section{A. Kesimpulan}

Hasil penelitian menjelaskan, bahwa 1) implementasi teknis behavior contract ini ada beberapa tahap pelaksanaanya. Pertama 
konselor mengawali pertemuan dengan konseli untuk membentuk keakraban, dengan maksud agar tidak terjadi ketakutan atau kekakuan oleh konseli karena paradigma konseli setiap yang berhubungan dengan BK adalah menyeramkan. Keduda, menentukan data awal yakni tingkah laku dari konseli yang mana yang akan dirubah, dan dilanjut proses pembuatan kontrak antara konselor dengan konseli. Ketiga, konselor menetapkan jenis penguatan serta yang akan diterapkan setiap kali tingkah laku yang diinginkan ditampilkan oleh konseli, pemberian penguatan maupun reward kepada konseli diberikan sesering mungkin agar konseli semakin termotivasi. 2) Sementara hasil dari teknik behavior contract untuk memotivasi siswa dalam menyelesaikan PR siswa MTsN Pilangkenceng Madiun sudah cukup baik. Hasil dari proses konseling tersebut menyatakan bahwa kedua konseli itu menghasilkan berubahan perilaku yang cukup baik

\section{DAFTAR PUSTAKA}

Ahmadi, Abu. 1991. Psikologi belajar.: rineka cipta. Jakarta

Ali, H. M. Sayuthi. 2002 .Metodologi Penelitian Agama: Raja GrafindoPersada Jakarta

Arikunto, Suharsimi.2002. Prosedur Penelitian (suatu pendekatan praktek edisiRineka Cipta,Jakarta

Badrujaman, Aip. 2011.Teori danaplikasi evaluasi program bimbingankonseling:Indeks, Jakarta

Carol, Wade, Carol, Tavris. 2007. Psikologi: Jilid 2: Erlangga,Jakarta

Cialdini, robert. 2005. Psikologi persuasif merekayasa kepatuhan:Prenada Media,Jakarta

Corey. 2005. Teori dan Praktek Konseling \& Psikoterapi.: P.T. RefikaAditamaBandung

Dahlan, M.D.1985. Beberapa pendekatan dalam penyuluhan (konseling): cv. Diponegoro, Bandung
Dahlan, M. 2003. Kamus induk istilah ilmiyah : Target press,Surabaya

Early. 1987. "Perencanaan Tugas dan EnergiCurahan: Eksplorasi BagaimanaTujuan Pengaruh Kinerja”, Jurnal Psikologi

Furchan, Arif. 1982. Pengantar Penelitian Dalam Pendidikan.: UsahaNasional,Surabaya

Judy, Cameron; w. David, pierce.1994. Penguatan, Reward, dan MotivasiIntrinsik: sebuah Meta-Analisis, Ulasan Penelitian Pendidikan, tanpa penerbit.

Khan, Wahiduddin, Maulana. 2003. Psikologi kesuksesan belajar dari kegagalandan keberhasilan: Jakarta : Robbani Press,

King, Laura A. 2007. Psikologi umum sebuah pandangan apresiatif. Jakarta: Salemba Humanika,

Komalasari, Gantina. 2011. Teori dan teknik konseling: PT. Indeks, Jakarta

Latipun. 2008. Psikologi Konseling: UMM Press,Malang

Maslo Abraham Harold.1954. Motivasi dan kepribadian.: New York : Harper\& Row.

Moleong, Lexy J. ,1996. Metodologi Penelitian Kualitatif: PT. Bandung : RemajaRosda karya

Mulyana, Dedi. 2002.Metode Penelitian Kualitatif. Bandung: Remaja Rosda Karya

Nurbuko, Cholid dan Ahmadi, Abu. 1997. Metodologi Penelitian. Bumi Aksara, Jakarta

Qodratilah, Meity taqdir. 2011. Kamus bahasa indonesia untuk pelajar:badan pengembangan dan pembinaan bahasa, Jakarta : kementerian pendidikan dankebudayaan,

Robbins, Stephen P.; Judge, Timothy A.2008. Perilaku Organisasi. Jakarta : Salemba Empat, 
Santoso, Slamet. 2010. Teori-teori Psikologi Sosial. Refika Aditama,Bandung

Subagyo, Joko. 2004. Metodologi dalam Teori dan Praktek. Rineka cipta, Jakarta

Sudarsono. 1997. Kamus konseling. Jakarta : Rineka cipta.

Sukardi, Dewa ketut. 1983. Bimbingan dan penyuluhan belajar di sekolah. Surabaya: Usaha Nasional,
Surya, Muhammad dan Jumhur. 1975. Bimbingan dan Penyuluhan di Sekolah. Bandung : Pustaka Ilmu

Usman, Husaini dan Akbar, Purnama Setiadi. 2000. Metodologi penelitian social., Jakarta : Bumi Aksara

Waluya, Bagja. 2007. Sosiologi: Menyelami Fenomena Sosial Di Masyarakat. Bandung : PT Grafindo Media Pratama 